\title{
The Neostratotype of Itapecuru Formation (Lower-Middle Albian) and Its Impact for Mesozoic Stratigraphy of Parnaíba Basin
}

\author{
FRANCISCO J. CORRÊA-MARTINS ${ }^{1,2}$ \\ ${ }^{1}$ Programa de Pós-Graduação em Geologia, Universidade Federal do Rio de Janeiro, Avenida \\ Athos da Silveira Ramos, 274, Ilha do Fundão, 21910-200 Rio de Janeiro, RJ, Brazil \\ ${ }^{2}$ Departamento de Geociências, Instituto de Agronomia, Universidade Federal Rural \\ do Rio de Janeiro, BR-465, Km 7, 23897-000 Seropédica, RJ, Brazil \\ Manuscript received on July 23, 2018; accepted for publication on December 21, 2018
}

\begin{abstract}
How to cite: CORRÊA-MARTINS FJ. 2019. The Neostratotype of Itapecuru Formation (Lower-Middle Albian) and Its Impact for Mesozoic Stratigraphy of Parnaíba Basin. An Acad Bras Cienc 91: e20180730. DOI 10.1590/00013765201920180730 .
\end{abstract}

\begin{abstract}
This study defines the neostratotype of the Lower-Middle Albian Itapecuru Formation in the Parnaíba Basin, Northeast Brazil. In this sedimentary succession along the right bank of the Itapecuru River near the Itapecuru-Mirim City, Maranhão State, three lithofacies associations are recognized. The first is silty claystone with some very fine sand, micaceous, reddish color, thin laminated, showing a tabular aspect, interpreted as floodplain fines in a distal position. The second is clayey siltstone, reddish color, with ripple cross-lamination, very thin cross-laminated wacke lenses, grading to thin parallel lamination, in apparently tabular layers, interpreted as crevasse splay and distributive channels deposits in successive avulsion events. The third is fine quartz wacke, reddish to grayish color, showing grouped trough cross bedding, interpreted as channel filling deposits. These facies associations correspond to part of a fluvial depositional system, with predominantly fine-grained rocks, and small lakes in the floodplain, in an oxidizing environment and marked by seasonality. These field data, reinforced by grain size and petrographic analyses showed that, contrary to previous descriptions, the Itapecuru Formation consists mainly of mudrocks. This research also shows that the medium to coarse sandstones and conglomerates, previously included in the Itapecuru Formation, belong to the underlying Grajaú Formation.
\end{abstract}

Key words: Itapecuru Formation, lithofacies, mudrocks, neostratotype, Mesozoic Stratigraphy, Parnaíba Basin.

\section{INTRODUCTION}

The Itapecuru Formation, as first proposed by Campbell (1949) in Maranhão or Parnaíba Basin, is predominantly constituted of sandstones (e.g. Mesner and Wooldridge 1962, 1964, Góes and

E-mail: correa_martins@ufrrj.br

ORCID: https://orcid.org/0000-0001-9430-3667

* Contribution to the centenary of the Brazilian Academy of Sciences.
Feijó 1994, Nascimento and Góes 2007, Vaz et al. 2007, Klein and Sousa 2012). It is the most widely outcropping Cretaceous unit and presents the largest outcropping surface of this intracontinental Paleo Mesozoic basin. The type locality is within the city of Itapecuru-Mirim (Campbell 1949), and the type section was informally established on the right bank of the Itapecuru River by Ferreira et al. (1992), under the BR-222 road bridge, which gives 
access to the town of Itapecuru-Mirim (Carvalho 1994). Nevertheless, Batista et al. (1984), in the Brazilian Stratigraphic Lexicon defined the type locality on the eastern coast of Pará State and the western coast of the Maranhão State. However, recent detailed geological mapping in Rosário County, in the north of Maranhão State (F.J. Corrêa-Martins, unpublished data), revealed that the outcrops of Itapecuru Formation correspond mainly to claystones and siltstones. These findings motivated the reexamination of the informal type section, located about $60 \mathrm{~km}$ south of Rosário city. In addition, due to constructions performed between 2012 and 2014 on the aforementioned bridge after heavy rains in 2009 (Departamento Nacional de Infraestrutura de Transportes - DNIT, unpublished data), the type section has been destroyed. Therefore, the objective of this paper is to formalize the neostratotype of the Itapecuru Formation (according to Hedberg 1976, Petri et al. 1986, Murphy and Salvador 1999).

\section{MATERIALS AND METHODS}

The results of this study came from a detailed field description and interpretation of the stratigraphic section, exposed on the right bank of Itapecuru River, done in the dry season, in October, 2015. Rock samples were collected for granulometric and petrographic analyses, and analysis of sedimentary textures (Picard 1971, Lundegard and Samuels 1980, Miall 1996, Boggs 2009, Lazar et al. 2015) and hues (Munsell 2009), to establish lithofacies (Picard 1971, Lundegard and Samuels 1980, Miall 1996, Boggs 2009, Lazar et al. 2015). These steps were necessary because most of the rocks samples are very fine-grained, which makes direct evaluations inaccurate (Pettijohn et al. 1972, Boggs 1995, 2006, Miall 2016).

The thin sections were examined in a Zeiss Axio Imager A.1 petrographic microscope, of Sedimentary Geology Laboratory (LAGESED),
Department of Geology, Institute of Geoscience of the Federal University of Rio de Janeiro (UFRJ). The textural analyses were carried out in the Sedimentology Laboratory of Department of Geoscience, Institute of Agronomy, Federal Rural University of Rio de Janeiro (UFRRJ).

An architectural panel was designed from photographic mosaics of outcrops and the definition of two-dimensional geometry. The definition of lithofacies is based on the determination of the grain-size and the sedimentary structures, following the proposals of Miall (1978, 1996). The facies are grouped into facies successions, or groups of lithofacies genetically related to each other, corresponding to sub-environment of a depositional system (Dalrymple 2010).

Samples for palynological and geochemical analyses were also collected, aiming to provide support to our interpretations.

\section{GEOLOGICAL SETTING}

The Parnaíba Basin, formerly known as Maranhão Basin, is an intraplate sag basin with asymmetric shape and area of ca. $600,000 \mathrm{~km}^{2}$ (Campbell et al. 1949, Mesner and Wooldridge 1962, 1964), filled with sedimentary and magmatic rocks, with maximum estimated thickness of 3,500 $\mathrm{m}$ (Vaz et al. 2007). The basin occupies large areas of the states of Maranhão (MA) and Piauí (PI), covering small portions of Ceará (CE), Bahia (BA), Tocantins (TO) and Pará (PA) (Figure 1). Currently, its basin limits are constrained the Ferrer-Urbano Santos High (AFUS to the north), to the east by the Borborema Province, to the south by the São Francisco High (ASF), to the west by the Tocantins Province and to the northwest by the Tocantins or Capim High (ATC). Recent seismic studies (Daly et al. 2014) suggest that its basement is compartmentalized, with the Amazon Craton and the Province of Tocantins in the western part, the Parnaíba Block in the central west portion, as suggested by Brito 


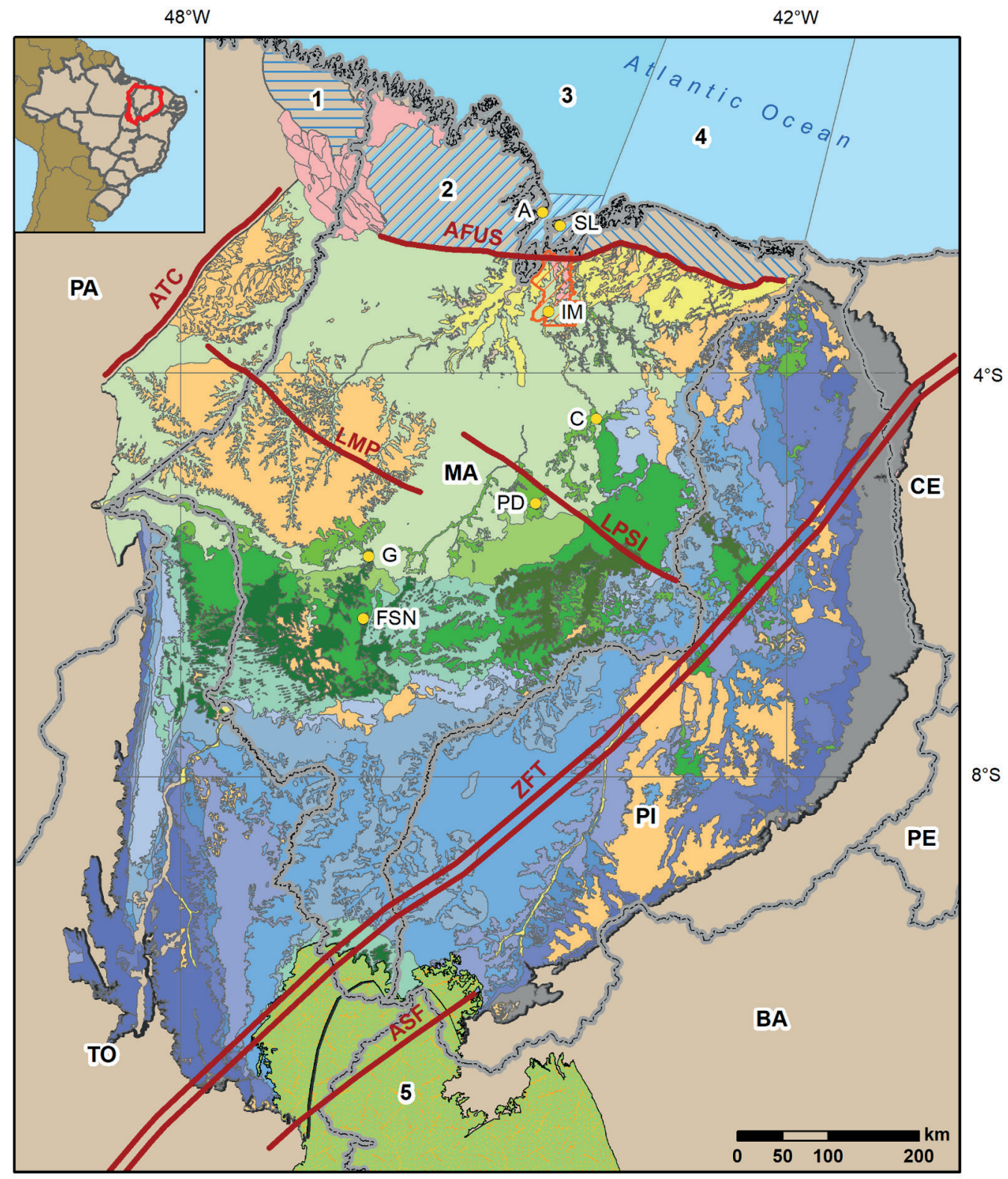

Source: Modified of Carta Geológica do Brasil ao Milionésimo, Sistema de Informações Geográficas. Programa Geologia do Brasil. CPRM, 2004.

Geodetic Information System SIRGAS 2000 Equiretangular Projection Normal Cylindrical

\section{— Parnaíba Basin}

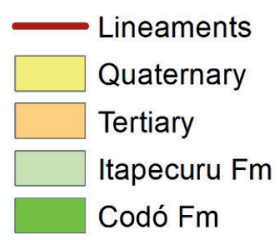

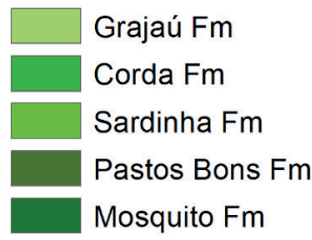

Mosquito Fm

\section{Q7 Study Area}

\begin{tabular}{|l|l|l|}
\hline & Sambaíba Fm & Longá Fm \\
\hline & Motuca Fm & Cabeças Fm \\
\hline & Pedra de Fogo Fm & Pimenteiras Fm \\
\hline & Piauí Fm & Serra Grande Gr \\
\hline Poti Fm & São Luís Craton
\end{tabular}

Figure 1 - Geologic simplified map of Parnaíba Basin, showing the limits, some structures, cities referred to in this work and other basins (1) Bragança-Viseu, (2) São Luís, (3) Pará-Maranhão, (4) Barreirinhas and (5) Sanfranciscana. For abbreviations see text. 
Neves et al. (1984), and the Province of Borborema to the east. The Marajó-Parnaíba (LMP) and PicosSanta Inês (LPSI) lines and the Transbrasiliano Lineament (Figure 1) controlled the depositional axes of the basin (Fortes 1978, Vaz et al. 2007).

The essentially siliciclastic rocks that fill the Parnaíba Basin can be divided into cycles delimited by unconformities or super sequences, resulting from both sea level fluctuations and tectonics, in the context of formation and disintegration of Gondwana and Pangea supercontinents. The first super sequence is Silurian in age, represented by the Serra Grande Group, which includes the Ipu, Tianguá and Jaicós formations. It is followed by the mid Devonian-Lower Carboniferous Canindé Group (Itaim, Pimenteiras, Cabeças, Longá and Poti formations), Lower Carboniferous-Lower Triassic Balsas Group (Piauí, Pedra de Fogo, Motuca and Sambaíba formations), Jurassic Pastos Bons Formation, and the Cretaceous units defined as the Corda, Grajaú, Codó and Itapecuru formations (Góes and Feijó 1994, Vaz et al. 2007, Linol et al. 2016).

The basic igneous rocks occur mostly as intrusions within the layers, while extrusions are restricted. The ages of basic magmatism ranges between 215 and $87 \mathrm{Ma}$, grouped into two formations: the Lower Jurassic Mosquito Formation in the center-west, and the Cretaceous Sardinha Formation in the center-east and northeast (Góes and Feijó 1994, Vaz et al. 2007, Linol et al. 2016) (Figure 1).

In recent years there have been proposals for subdivisions of the Parnaíba Basin infilling, separating the Mesozoic section into other basins, as Grajaú, Alpercatas and Espigão-Mestre basins (Góes and Coimbra 1996) or São Luís-Grajaú (Góes and Rossetti 2001), but their acceptance has been restricted (Klein and Sousa 2012).

\section{ITAPECURU FORMATION: HISTORICAL PERSPECTIVE}

In the 1940s, the National Petroleum Council started the geological mapping of the Parnaíba Basin, also known as the Maranhão Basin. After fieldwork carried out in the southern and central portions of the basin, Campbell et al. $(1948,1949)$ proposed the Serra Negra Formation, of Tertiary age, for layers of sedimentary rocks located between the Codó and Barreiras formations, based on the outcropping rocks in Serra Negra, the type locality, near Formosa de Serra Negra city (FSN), about 80 $\mathrm{km}$ south of the city of Grajaú (G), MA (Campbell et al. 1948, Baptista et al. 1984) (Figure 1). This new formation was divided into two members: Sopé (lower), composed of soft red and gray shales, with some sandstone lenses and few carbonate, and Serra, consisting predominantly of fine quartzose sandstone with cross stratification and silt reddish brown to pink, with a few thin layers of reddish shale, and occasional occurrence of coarser sand and pebbles deposited in a continental environment (Campbell et al. 1949, Figure 2a).

Posteriorly, the discovery of dinosaurs fossils in Livramento Island, São Marcos Bay, (Price 1947) and the recognition of predominance of very finegrained rocks that extend to the coast of Maranhão, led Campbell (1949) to reconsider the Serra Negra rocks as a member of a new unit, the Itapecuru Formation, whose name derives from the outcrops found near city of Itapecuru-Mirim, MA (IM) (Figure 1), which characterize practically all the rocks found in the unit. Campbell (1949) divided the Itapecuru Formation, of Cretaceous age, which includes all strata above the Codó Formation and below the Pirabas Formation, in three members, the former Serra Negra Formation, Undifferentiated and Boa Vista. Therefore, Carvalho and Campos (1988) committed a mistake when they said that the division had resulted in two members. 
The intermediate member, called "Undifferentiated", constituted of shale and interbedded sandstone, siltstone, silty shale, shale and claystone. The strata are predominantly micaceous and principal colors are dusky to moderate red with some greenish gray beds and mottling and occur in the central and northern part of the basin. Only near Alcântara city (A), to the northwest of São Luís Island (SL), some limestone beds occur (Figure 1). Campbell (1949) established the type locality this member is the banks of Itapecuru River near of Itapecuru-Mirim city (IM) (Figures 1, 2a).

The upper member, "Boa Vista", consists of siltstone, fine-grained sandstone and silty shale, usually massive, and the predominant colors are red, gray and brown, with light shades. The name and type locality of this member comes from the Serra da Boa Vista, $10 \mathrm{~km}$ NE of Curator city, MA, now President Dutra (PD) (Figures 1, 2a).

Campbell (1949) considered that most of the Itapecuru Formation represents a continental paleoenvironment, and only in the north of the basin, in the region of Alcântara, the presence of limestone layers and invertebrate fossils suggest a marine paleoenvironment. This conclusion was reached after these data were synthesized without indicating the type localities (Campbell 1950).

Later Mesner and Wooldridge (1962) made a revaluation study of the Parnaíba Basin for Petróleo Brasileiro S.A (Petrobras), based on previous studies, deep wells and seismic surveys they proposed the marginal basins of São Luís and Barreirinhas, which extend approximately parallel with the present coastline of Maranhão State, thus dividing the northern portion of the Parnaíba Basin (Figure 1). However, when the data were published (Campos 1964, Mesner and Wooldridge 1964), the characterization of the Itapecuru Formation was simplified, bringing together the three members in an undivided formation (Figure 2a), constituted for a series of variegated sandstones, siltstones, and shales, with usually reddish and greenish colors. According to Mesner and Wooldridge $(1962,1964)$, the Itapecuru Formation is predominantly nonmarine in Parnaíba Basin, with floodplain facies, as valley-flat and alluvial plain, gradually changing to deltaic facies in São Luís Basin (Figure 2b).

In a revision of the Parnaíba Basin, Aguiar (1969, 1971) proposed new lithostratigraphic unites, notedly the Grajaú Formation, initially characterized as fine sandstone to conglomerate, white to yellowish color, with laminar cross stratification underlying Codó Formation. Aguiar $(1969,1971)$ also proposed the Alcântara Formation, near the city of the same name, for São Luís Basin, proposed by Cunha (1968) in an internal report. This unit consists of greenish-reddish gray shales, silty, with limestone lenses, lithofacies described by Campbell (1949) in the same area when he proposed the Itapecuru Formation. Its rocks are exposed on the cliffs near the Alcântara city and have been correlated with the limestones that appear in some parts of the island of São Luís. However, Aguiar $(1969,1971)$ incorrectly included the Alcântara Formation in the stratigraphic column of the Parnaíba Basin, because that unit only occurs in the São Luís Basin (Figure 2a, b).

In studies carried out for Petrobras in the centerwest portion of the Parnaíba Basin, Carneiro (1974) verified that the sandstones and conglomerates of the Grajaú Formation are interdigitated with the bituminous shales, limestone and anhydrite of the Codó Formation and, in this case, the conglomerates and sandstones of the Grajaú Formation become clayey and slightly limestone (Figure 2a).

Lima and Leite (1978) in studies for Companhia de Pesquisa de Recursos Minerais (CPRM), verified that Grajaú rocks occurring both below and above Codó Formation, and its contacts are predominantly gradational, with some local unconformities (Figure 2a). Moreover, verified that the rocks existing in the type localities proposed for the lower and upper members of the Itapecuru Formation by Campbell 
(1949), respectively Serra Negra [near Formosa de Serra Negra (FSN)] and Boa Vista [Presidente Dutra (PD)] (Figure 1) pertain, in the first case, to Corda and Grajaú formations and, in the second case, to Grajaú and Codó formations. Those authors agree to characterize the depositional environment of the Grajaú rocks as deltaic, agreeing with Carneiro (1974).

Cerqueira and Marques (1985) considered that the sandstones of Grajaú Formation in São Luís Basin could eventually become more clayey, as Carneiro (1974) had already observed in the Parnaíba Basin.

In general, most studies has followed Mesner and Wooldridge $(1962,1964)$, that characterized the Itapecuru Formation constituted of sandstones and mudrocks, deposited in a fluvial paleoenvironment (e.g. Aguiar 1969, 1971, Carneiro 1974, Aranha et al. 1988, 1990, Cunha and Del'Arco 1988, Santos and Mamede 1990, Góes and Feijó 1994, Gonçalves and Carvalho 1996). Lima and Leite (1978) also accompanied the lithological characterization, and considered that the Itapecuru Formation resulted from sedimentation in fluvial environment, with associated lakes and flood plains, in semi-arid climate due to the extensive oxidizing character of the rocks.

Posteriorly Rossetti and Truckenbrodt (1997), based on informal divisions made in Itapecuru Formation by Aranha et al. $(1988,1990)$ in São Luís Basin (Figures 1, 2b), proposed the elevation to category of group with three formations, "Undifferentiated Unit", Alcântara and Cujupe formations (Figure 2b). The Itapecuru Group (sensu Rossetti and Truckenbrodt 1997), and Grajaú and Codó formations was separate from the Parnaíba Basin, to constitute the Grajaú Basin (Góes et al. 1999), later transformed into the São Luís-Grajaú Basin (Góes and Rossetti 2001). Rossetti (2001), based in regional unconformities interpreted in gamma-ray and seismic data, divided the rocks of the São Luís-Grajaú Basin into three depositional sequences (S1, S2 and S3), establishing a correlation with the stratigraphic column proposed by Rossetti and Truckenbrodt (1997) (Figure 2b). Based on these proposals, in several studies carried out (e.g. Anaisse et al. 2001, Rossetti et al. 2000, 2001, Rossetti and Góes, 2003, Miranda and Rossetti 2006, Nascimento and Góes, 2007, Nascimento et al. 2007, Mendes and Truckenbrodt 2009), the "Undifferentiated Unit" or S2 and part of S3 is described as consisting of fine and coarse sandstones, eventually conglomerates, possibly with matrix, limestones and mudrocks, and interpreted as fluvial-deltaic environment, flowing into a protected bay or gulf.

In a review of the Parnaíba Basin for Petrobras, Vaz et al. (2007) adopted the depositional sequences proposed by Góes and Rossetti (2001) but, confusingly, show the interdigitated Itapecuru and Codó formations, reproducing the proposal of Góes and Feijó (1994), in erosive contact with the underlying Corda, Grajaú and Codó formations, for which they propose a relation of contemporaneity (Figure 2a).

\section{THE NEOSTRATOTYPE OF ITAPECURU FORMATION}

According to Hedberg (1976), Petri et al. (1986) and Murphy and Salvador (1999), the establishment of the neostratotype must meet the same requirements used for the formalization of the stratotype.

\section{JUSTIFICATION AND NAME}

Campbell (1949) first proposed the name of Itapecuru Formation, widely distributed in the north central portion in Parnaíba Basin, being initially composed of three members named Serra Negra, Undifferentiated and Boa Vista, forming a lithological complex mapped both on the surface and in the subsurface. The name derives from the river where there are outcrops of the unit, next to city of Itapecuru-Mirim, MA. According to Mesner and Wooldridge $(1962,1964)$ and Aranha et al. 


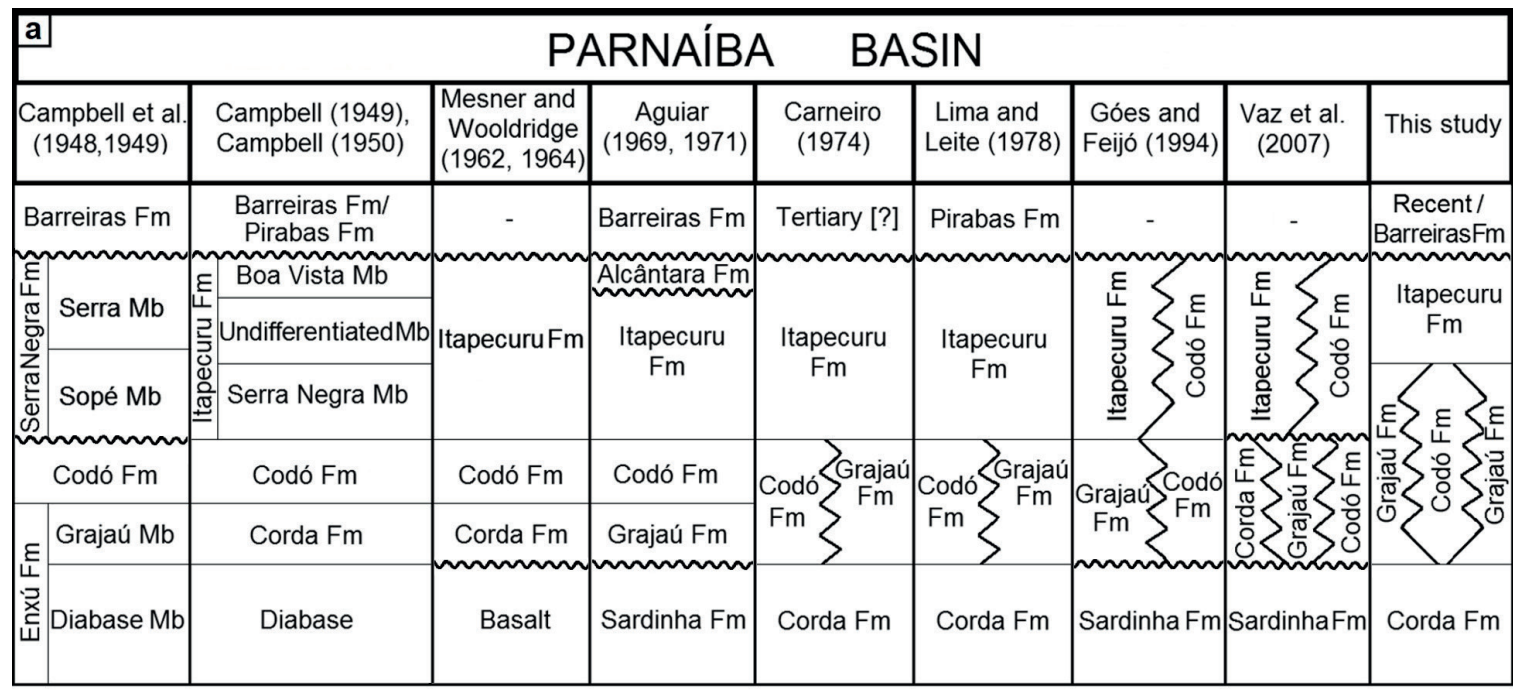

\begin{tabular}{|c|c|c|c|c|c|}
\hline & \multicolumn{4}{|c|}{ SÃO LUÍS BASIN } & \multirow{2}{*}{$\begin{array}{c}\text { SÃO LUÍS-GRAJAÚ BASIN } \\
\text { Rossetti (2001) }\end{array}$} \\
\hline & $\begin{array}{l}\text { Mesner and } \\
\text { Wooldridge } \\
(1962,1964)\end{array}$ & $\begin{array}{c}\text { Aguiar } \\
(1969,1971)\end{array}$ & $\begin{array}{l}\text { Aranha et al. } \\
(1988,1990)\end{array}$ & $\begin{array}{c}\text { Rossetti and } \\
\text { Truckenbrodt (1997) }\end{array}$ & \\
\hline \multirow{5}{*}{$\begin{array}{l}\text { Legend } \\
\text { Fm - Formation } \\
\text { Gp - Group } \\
\text { S - Depositional Sequence } \\
\text { Syst - System }\end{array}$} & \multirow{4}{*}{ Itapecuru $\sum_{\text {Fm }}^{\text {Pirabas Fm }}$} & \multirow{4}{*}{$\underbrace{\text { Barreiras Fm }}_{\text {Alcântara Fm }}$} & Pirabas Fm & \multirow{4}{*}{$\begin{array}{c}\text { Pirabas Fm/ } \\
\text { Barreiras Fm } \\
\text { Un? Cuj? }\end{array}$} & \multirow{4}{*}{ S3 } \\
\hline & & & E्E ITA IV & & \\
\hline & & & 5 & & \\
\hline & & & $\stackrel{0}{\cong}$ ITA I & & \\
\hline & Codó Fm & Codó Fm & $\begin{array}{c}\text { Codó/Grajaú } \\
\text { Syst }\end{array}$ & Codó Fm / Grajaú Fm & s1 \\
\hline
\end{tabular}

Figure 2 - (a) The stratigraphic position of the Itapecuru Formation and other underlying and overlying formations in the Parnaíba Basin, according to the mentioned authors. (b) The stratigraphic position of the Itapecuru Formation, of the Itapecuru Group and other underlying and overlying formations in the São Luís and São Luís-Grajaú basins, according to the mentioned authors.

$(1988,1990)$, the formation also occurs in São Luís and Bragança-Viseu basins.

\section{HIERARCHY}

Campbell (1949) defined the unit as a formation. Rossetti and Truckenbrodt (1997) proposed the elevation of the Itapecuru Formation to the category of group in the São Luís Basin and later in the Grajaú-São Luís Basin, and some authors followed these propositions. It is recommend maintaining the unit as formation, because the hierarchical change was proposed for another basin and the detailed description of the distinctive characters of the "Undifferentiated Unit" of "Itapecuru Group" of Rossetti and Truckenbrodt (1997) was not made, in disagreement with the Brazilian Stratigraphic Nomenclature Code (Petri et al. 1986) and with the International Stratigraphic Guide (Hedberg 1976, Murphy and Salvador 1999).

\section{LOCALIZATION}

Campbell (1949) defined the type locality in outcrops on the banks of the Itapecuru River, next to city of Itapecuru-Mirim, state of Maranhão (Figures $2 \mathrm{~b}, 4 \mathrm{a})$. The neostratotype is established in the right bank of the Itapecuru River, about 200 meters to the northeast of the river bridge $\left(03^{\circ} 23^{\prime} 28,0^{\prime \prime} \mathrm{S}\right.$, $\left.44^{\circ} 21^{\prime} 35,9^{\prime \prime} \mathrm{W}\right)$, accessed by an old ramp at the end of Senador Benedito Leite Street (Figures 3c, 4b). 


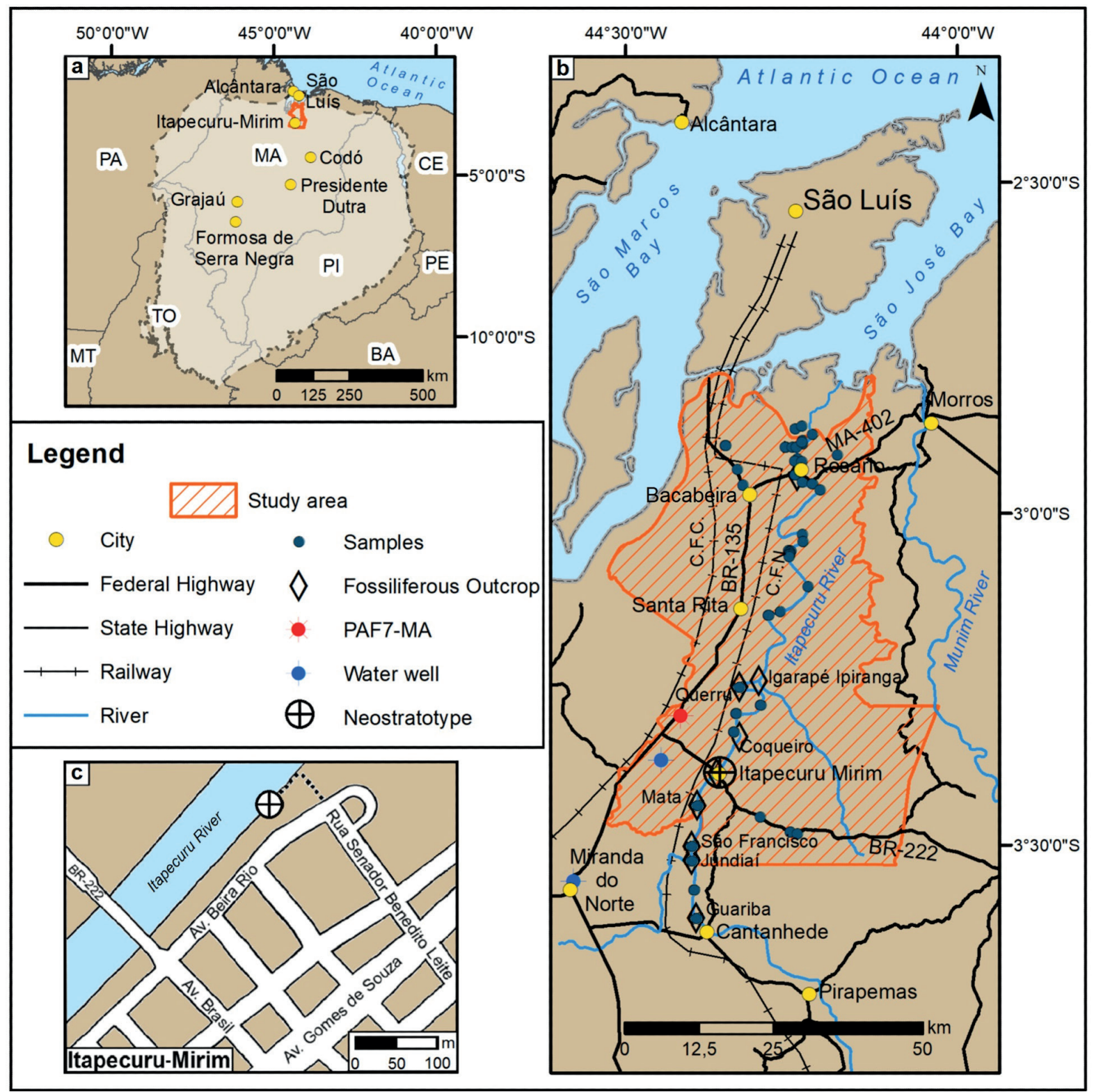

Figure 3 - (a) Location of the Parnaíba Basin in Northeastern Brazil, with cities referred. (b) Map of outcrops of the Itapecuru Formation in the northern portion of the Itapecuru River, which represent some places discussed in this paper. (c) Location of the neostratotype of Itapecuru Formation.

\section{DESCRIPTION}

\section{Lithofacies, associations and interpretations}

In this work, detailed observation of outcrops enabled the establishment of five lithofacies, and three lithofacies associations, as summarized in Table I. The percentages reported below refer to the average observed.
Lithofacies Wt - Fine Wacke, composed by fine sand $(70 \%)$, coarse to medium silt $(25 \%)$ and clay (5\%), reddish to grayish color (10R 8/2N8), with subangular to subrounded grains of monocrystalline quartz (91\%), plagioclase (8\%), muscovite $(1 \%)$ and few opaque minerals $(<$ $1 \%$ ), with local carbonate cementation. It shows grouped trough cross bedding with fining-upward 
TABLE I

Lithofacies and architectural elements recognized in the neostratotype of Itapecuru Formation, along the right bank of Itapecuru River, Itapecuru-Mirim City, Maranhão State, Brazil. Lithocodes are adapted from Miall (1978, 1996).

\begin{tabular}{|c|c|c|c|c|c|c|}
\hline $\begin{array}{c}\text { Lithofacies } \\
\text { Code }\end{array}$ & Rocks & $\begin{array}{c}\text { Sedimentary } \\
\text { Structures }\end{array}$ & Interpretation & $\begin{array}{c}\text { Architectural } \\
\text { elements }\end{array}$ & Geometry & Interpretation \\
\hline $\mathrm{Wt}$ & $\begin{array}{c}\text { Fine } \\
\text { Wacke }\end{array}$ & $\begin{array}{l}\text { Grouped trough } \\
\text { cross-beds }\end{array}$ & $\begin{array}{l}\text { Sinuous-crests and } \\
\text { linguoid (3-D) dunes }\end{array}$ & $\begin{array}{l}\text { Channel-Sand } \\
\text { Bed Form } \\
\text { (CH-SB) }\end{array}$ & $\begin{array}{c}\text { Sheet-shaped } \\
\text { deposit }(\mathrm{w} / \mathrm{d}<30) \\
\text { with concave } \\
\text { lower erosive } \\
\text { surface }\end{array}$ & $\begin{array}{c}\text { Channel fill } \\
\text { by subaqueous } \\
\text { dunes }\end{array}$ \\
\hline $\mathrm{Wp}$ & $\begin{array}{l}\text { Very fine } \\
\text { Wacke }\end{array}$ & $\begin{array}{l}\text { Grouped planar } \\
\text { cross-beds }\end{array}$ & $\begin{array}{l}\text { Transverse and } \\
\text { linguoid bedforms } \\
\text { (2-D dunes) }\end{array}$ & $\begin{array}{c}\text { Crevasse- } \\
\text { Channel (CR) }\end{array}$ & $\begin{array}{l}\text { Sheet-shaped/ } \\
\text { aligned lenses, } \\
\text { with concave } \\
\text { lower erosive } \\
\text { surface }\end{array}$ & $\begin{array}{c}\text { Tertiary } \\
\text { distribution of } \\
\text { the Crevasse } \\
\text { Channel }\end{array}$ \\
\hline Sil & $\begin{array}{l}\text { Clayey } \\
\text { Siltstone }\end{array}$ & $\begin{array}{l}\text { Thin horizontal } \\
\text { lamination }\end{array}$ & $\begin{array}{l}\text { Overbank/waning } \\
\text { flood deposits }\end{array}$ & $\begin{array}{l}\text { Crevasse Splay } \\
\text { (CS) }\end{array}$ & Locally tabular & $\begin{array}{l}\text { Distal portion } \\
\text { of unconfined } \\
\text { crevasse lobes } \\
\text { that prograde } \\
\text { over floodplain }\end{array}$ \\
\hline Sir & $\begin{array}{l}\text { Clayey } \\
\text { Siltstone }\end{array}$ & $\begin{array}{l}\text { Climbing } \\
\text { ripple cross- } \\
\text { lamination }\end{array}$ & $\begin{array}{l}\text { Ripples (lower flow } \\
\text { regime) }\end{array}$ & $\begin{array}{l}\text { Crevasse Splay } \\
\text { (CS) }\end{array}$ & Locally tabular & $\begin{array}{l}\text { Proximal- } \\
\text { medium portion } \\
\text { of unconfined } \\
\text { crevasse lobes } \\
\text { that prograde } \\
\text { over floodplain }\end{array}$ \\
\hline $\mathrm{Cl}$ & Claystone & $\begin{array}{l}\text { Thin horizontal } \\
\text { lamination }\end{array}$ & $\begin{array}{c}\text { Waning flood } \\
\text { deposits/distal flood } \\
\text { deposits }\end{array}$ & $\begin{array}{l}\text { Floodplain } \\
\text { Fines (FF) }\end{array}$ & Tabular & $\begin{array}{c}\text { Floodplain } \\
\text { and floodbasin } \\
\text { deposits }\end{array}$ \\
\hline
\end{tabular}

and average thickness of $70 \mathrm{~cm}$. The deposition occurred through subaquatic traction currents. The sedimentary structures approach to the lithofacies St of Miall (1996) and Scherer et al. (2015), and the L3 of Gonçalves and Carvalho (1996) (Figure 4c).

Lithofacies $W p$ - Very fine silty-clayey Wacke, composed by very fine sand (75\%), fine silt (15\%) and clay (10\%), reddish color (5y 8/4 - 10R 7/4), with subangular to subrounded grains of monocrystalline quartz (93\%), plagioclase (6\%), muscovite (1\%) and few opaque minerals $(<1 \%)$, with some carbonate cementation, with small planar-cross stratification. Its thickness varies between 5 and $10 \mathrm{~cm}$, appearing either continuously or sometimes lenticular (10 $30 \mathrm{~cm}$ in width). The deposition occurred through underwater traction currents in the lower flow regime. The sedimentary structures are the same of the lithofacies Sp of Eberth and Miall (1991), and Miall (1996) (Figure 4c).
Lithofacies Sil - Clayey Siltstone, reddish color (5R 4/6 - 5R 6/6), with thin parallel lamination. It has an average thickness of $30 \mathrm{~cm}$, and its appearance is tabular. The deposition of this facies was interpreted as by decantation of particles in subaquatic medium. It presents sporadic plastic deformation by load at the top. The thin parallel lamination allows an approximation with the lithofacies F1 of Miall (1996) and with the L2 of Gonçalves and Carvalho (1996), in which fluidized levels were also registered (Figure 4c).

Lithofacies Sir - Clayey Siltstone, reddishcolored (5R 7/4 - 10R 8/2) with ripple crosslamination (critically climbing-ripples). It has tabular appearance and an average thickness of $50 \mathrm{~cm}$. This resulted from traction processes and settling of particles in a lower flow regime. The sedimentary structures were interpreted as to the 
lithofacies Sr of Miall (1996) and Sr-La3 of Simon and Gibling (2017) (Figure 4c).

Lithofacies $\mathrm{Cl}$ - Silty Claystone with some very fine sand, reddish color ( $5 \mathrm{R} 7 / 4$ to $5 \mathrm{R} 6 / 6)$, micaceous, with lamination $(2-8 \mathrm{~mm})$ sometimes incipient, little mottled. Its thickness, from the water level of the Itapecuru River, is about $70 \mathrm{~cm}$. The deposition of this facies was interpreted as predominantly resulted of suspended particles. This lithofacies is very similar in terms of grain size, sedimentary structures, thickness and geometry to the lithofacies Fl of Eberth and Miall (1991), L1 of Gonçalves and Carvalho (1996) and facies Fm of Scherer et al. (2015), while the mottled aspect approaches the lithofacies Fr of Miall (1996) (Figure 4c).

The succession of five lithofacies described allowed the establishment of three groups or lithofacies associations.

Floodplain Fines Association - Constituted by lithofacies $\mathbf{C l}$, with lateral continuity for more than twenty meters. The rocks are homogeneous, with predominance of clay. There are no intraclasts or other evidences of traction flow (Figure 5).

Interpretation - The layer geometry, extending tens of meters, allows interpreting the lithological set as representative of fine floodplain (FF element, Miall 1996), in a distal position. These characteristics are in accordance with low-energy cohesive floodplain (Nanson and Crooke 1992). Its reddish color indicates it was deposited in an oxidizing environment in semi-arid climate (Potter et al. 2005). The presence of small spots, with ellipsoidal shape of 2 to $3 \mathrm{~mm}$ of light green color, showing the reduction of $\mathrm{Fe}^{3+}$ to $\mathrm{Fe}^{2+}$ are interpreted as resulting from the activities of soft body invertebrates on the substrate, as Gonçalves and Carvalho (1996) had already recognized. The diagnostic horizons are incipient or absent, which allows classify as type entisol (Retallack 1988). Previously, Gonçalves and Carvalho (1996) interpreted the association as predominantly lacustrine sedimentation.

Crevasse Splay Association - This association is constituted by lithofacies Sir, $\mathbf{W p}$ and Sil, that occur in a succession of lithofacies and have lateral extension of several meters. The contact between the lithofacies Sir and Sil is gradational. The lithofacies Wp, which occurs at some levels within the range dominated by lithofacies Sir, presents erosive lower contact and the upper gradational superior (Figures 3c, 5).

Interpretation - This set of lithofacies is interpreted as constituent of crevasse splay (Miall 1996 element CS), resulting from crevasse lobes that prograde over the floodplain. The colors indicate sedimentation in an oxidizing paleoenvironment. Due to its sedimentary structures, the lithofacies Sil was deposited in a position more distant than the lithofacies Sir (Burns et al. 2017). In some points of the top of the lithofacies Sil convolute structures occur, indicating that it was not yet lithified. The lithofacies $\mathbf{W p}$, which occurs within the lithofacies Sir, is interpreted as distributive secondary and/or tertiary channels of crevasse channel, in successive events of avulsion (Smith et al. 1989, Stuart et al. 2014) (Figure 5). Previously Gonçalves and Carvalho (1996) interpreted the sedimentary structures of lithofacies L2, which correlate with lithofacies Sil, as the distal portion of river-mouth bars.

Channel Fill Association - This association is constituted by lithofacies $\mathbf{W t}$, in a bed of tabular appearance and estimated width of about twenty meters, with concave-erosive inferior contact with the lithofacies Sil of Crevasse Splay association. The sedimentary structures present low dipping and the paleocurrent indicators show small dispersion (Figure 5).

Interpretation - Due to this data set, the association is here interpreted as channel filling deposits (element $\mathrm{CH}$, Miall 1996) whose color indicates that it was deposited in oxidizing paleoenvironment. The carbonate cementation 


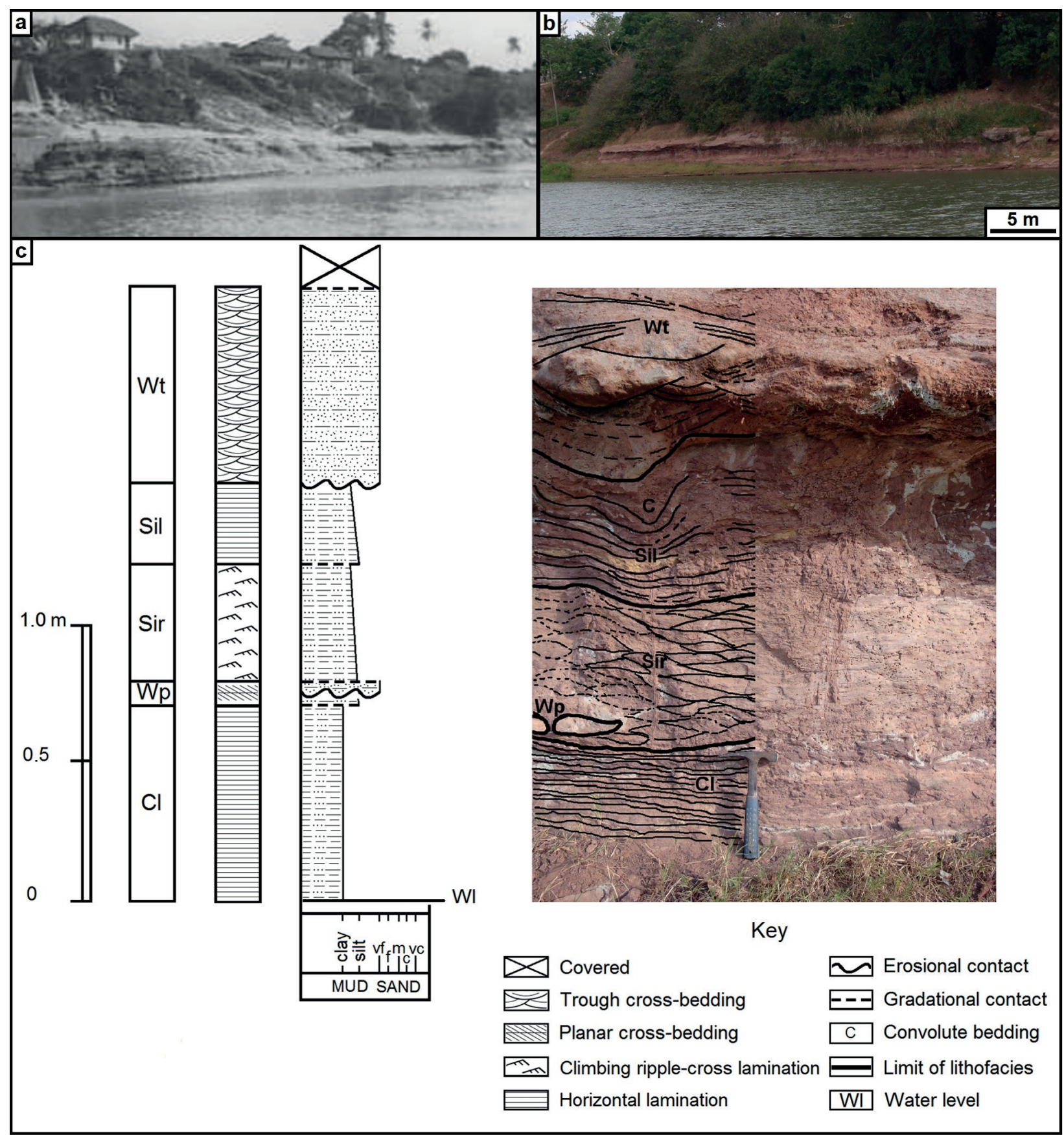

Figure 4 - (a) Outcrops on the right bank of the Itapecuru River, near the city of Itapecuru-Mirim, in the upstream direction. Image from Campbell (1949). (b) Image of the same outcrops obtained in 2015, downstream, where the neostratotype was established (see Figure 2c). (c) Sedimentological log and lithofacies highlighted of neostratotype of Itapecuru Formation. For codes of lithofacies, see Table I. 
that eventually occurs is the result of diagenetic events, which may be related to the weathering of plagioclase, or originate from preexisting units (Pettijohn et al. 1972), such as the Codó Formation. It should be noted that calcretes or $\mathrm{CaCO}_{3}$ concretions are absent. Before, Gonçalves and Carvalho (1996) interpreted this lithofacies, which denominated L3, as deltaic front deposits or river mouth bars deposits in an aqueous body as a relatively calm and shallow lake.

\section{PETROGRAPHIC ANALYSES}

The granulometric analyses confirmed the presence of silt and clay in all samples, at least $25 \%$ (lithofacies $\mathbf{W p}$ and $\mathbf{W t}$ ) and a maximum of 98\% (lithofacies Sil, Sir and $\mathbf{C l}$ ). The sand and silt grains show a little brightness, roundness from subangular to subrounded, and show elongate and equidimensional shapes (Figure 6a, b, c, d). There is no evidence of clay infiltration.

Because the friability and low cohesibility of the studied rocks, the diagenetic processes should have occurred at shallow depths. Due to these characteristics, the samples were impregnated to obtain thin sections. Under petrographic microscope, the mineral composition of the sand fraction is constituted essentially by monocrystalline quartz (91-93\%), followed by plagioclase (6-8\%) variably saussuritized, muscovite (1\%), and opaque minerals $(\leq 1 \%)$ (Figure 6a, b, d, f, g, h).

In the lithofacies $\mathbf{W p}$ and $\mathbf{W t}$, the contacts between grains of sand are punctual and longitudinal (Figure 6a-d). In the other lithofacies, when sand grains are present, they are immersed in mudrock (Figure 6e-h). Sand grains and even silts may be involved in oxidation films. The calcite cementation appears only in the lithofacies $\mathbf{W p}$ and $\mathbf{W t}$, sometimes in mosaic or poikilotopic form (Figure $6 \mathrm{~d})$. The occurrence of carbonized phytoclasts in all the studied samples has to be underlined. They are fine with elongated to equidimensional forms (0.01-0.03 $\mathrm{mm}$ ), being dispersed in the rocks (Figure 6).

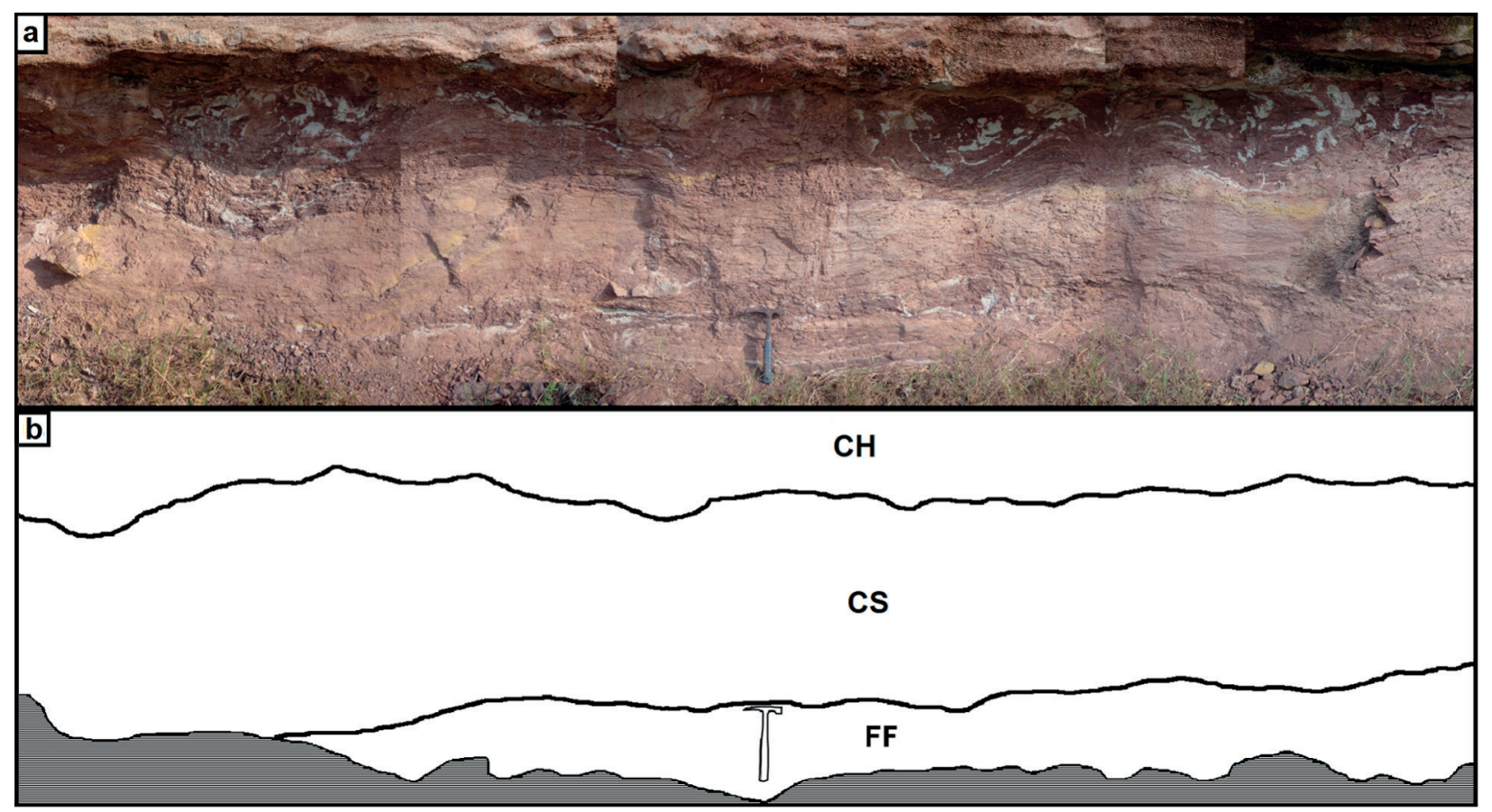

Figure 5 - Photomosaic (a) and interpreted outcrop panel (b) of Itapecuru Formation, including the neostratotype, showing different architectural elements, channel fill $(\mathrm{CH})$, crevasse splay $(\mathrm{CS})$ and floodplain fines association (FF). 


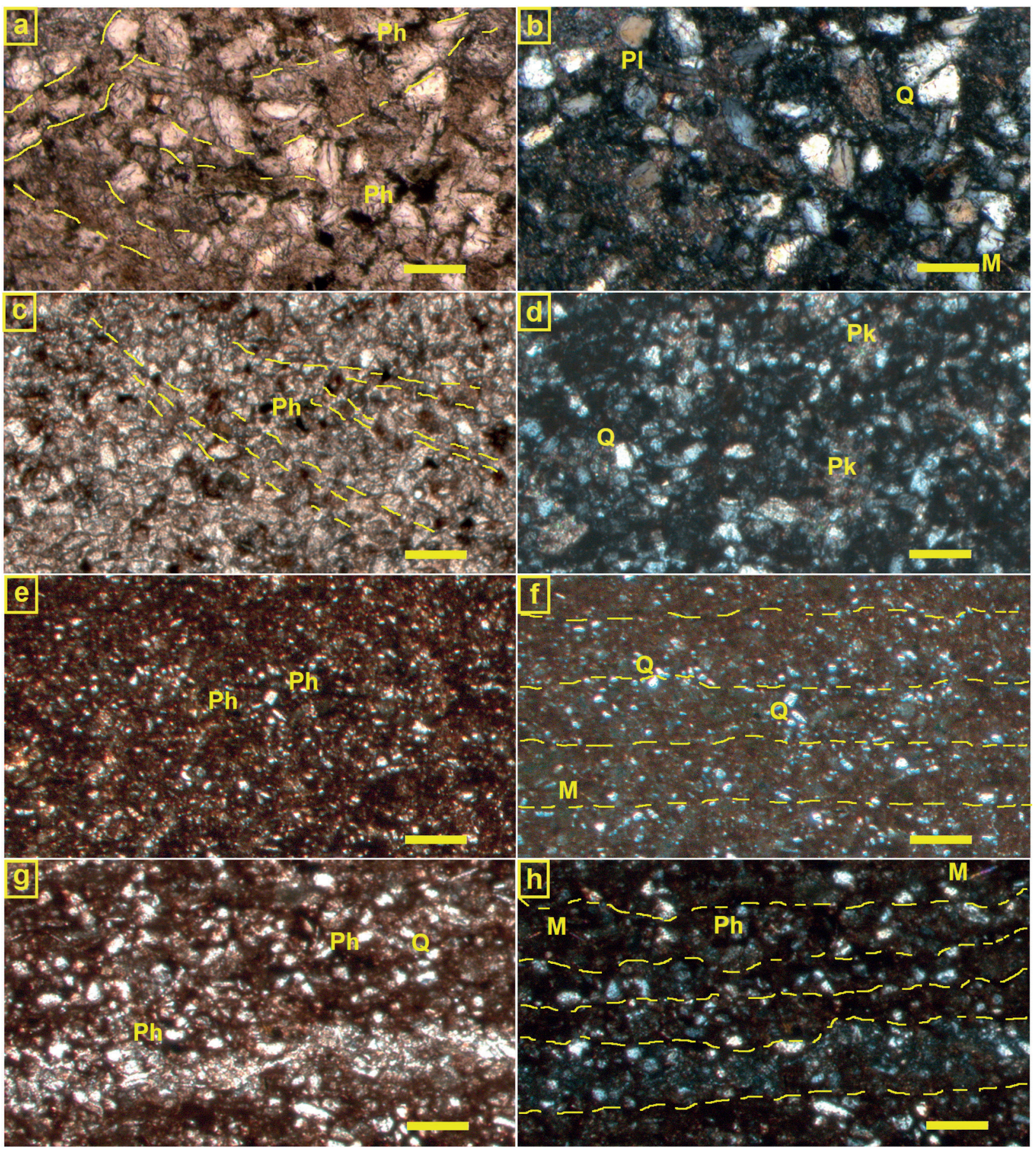

Figure 6 - Petrographic and sedimentary features of lithofacies Wt (a-b), Wp (c-d), Sil (e-f) and Sir (g-h) of the neostratotype of Itapecuru Formation. Plane-polarized light (a, c, e and $\mathbf{g})$ and cross-polarized light $(\mathbf{b}, \mathbf{d}, \mathbf{f}$ and $\mathbf{h})$. The dashed yellow lines highlight some incipient bedding surfaces. Q, quartz; Pl, plagioclase; M, muscovite, Pk, poikilotopic cementation; Ph, phytoclast. Bar scale $0.2 \mathrm{~mm}$. 
Complementing this data, the X-ray diffraction (XRD) of the total rock in the fraction below 0.062 $\mathrm{mm}$ revealed the predominance of quartz, followed by montmorillonite, also occurring kaolinite and illite (F.J. Corrêa-Martins, unpublished data). These results are very similar to those reported for same area by Menezes and Carvalho (1996) and Sachs et al. (2017).

\section{PALYNOLOGICAL AND GEOCHEMICAL DATA}

Samples of rocks of the neostratotype did not show palynological content. However, in samples collected to the north in outcrops studied in Rosário County correlated with neostratotype (F.J. CorrêaMartins, unpublished data), green algae of the Pediastrum genus, which does not support salinity, were found, which indicate fresh-water conditions.

The geochemical analyses carried out at ACME Lab, Canada, for the samples collected (F.J. CorrêaMartins, unpublished data), revealed that the Boron, which allows to evaluate paleosalinity, presents average values between $<1$ and $1 \mathrm{ppm}$, indicating a freshwater paleoenvironment (Figure 4b).

\section{LIMITS}

In the proposed neostratotype, the waters of the Itapecuru River hide the lower limit of the stratigraphic unit. The upper limit is covered by vegetation and sediments. At regional scale, the contacts with the underlying formations Grajaú and Codó, of the Lower Cretaceous, are transitional, while the contact with the overlying the Tertiary Barreiras Formation and the laterized soil cover are discordant (Carneiro 1974, Lima and Leite 1978).

\section{DIMENSIONS AND SHAPE}

The strata of the Itapecuru Formation are centimetric to metric, and the layers are mostly tabular, with very gentle dips, showing planar and low angle cross-bedding, besides planar structures and laminations, also occurring massive structures.

\section{FOSSIL CONTENT}

In the outcrops along the Itapecuru River, from Igarapé Jundiaí to the north, in localities like Mata, São Francisco and Itapecuru-Mirim different types of fossils were found. Among vertebrates, dinosaur (Sauropoda and Theropoda), crocodilians (Notosuchia), fish [Chondrichthyes (Hybodontidae) and Osteichthyes (Semionotidae, Lepisosteidae, Pycnodontidae, Amiidae, Mawsoniidae, and Ceratodontidae)] and chelonians (Pleurodira) (Carvalho and Campos 1988, Ferreira et al. 1991, Carvalho 1994, Santos and Carvalho 2009). Crustaceans (ostracods and conchostraceae), gastropods and bivalves (Anodonta) (Ferreira et al. 1992, 1995), were some of the invertebrates found (Figure 4b).

The palynological analysis in samples collected along the Itapecuru River, in outcrops located in Guariba (Cantanhede County), Coqueiro, Querru and Igarapé Ipiranga (Itapecuru County) and Rosário city (Figure 4b), revealed palynomorphs with the occurrence of Complicatiscus cearensis and Elateropollenites jardinei pollen zone. This association suggests that the depositional paleoenvironment was continental, fluvial, under hot and relatively humid climatic conditions (Pedrão et al. 1993, Pedrão 1995, Pedrão and Corrêa-Martins 1999, Ferreira et al. 2016).

Determined through the Complicatisaccus cearensis and Elateropollenites jardinei pollen zone, the first of Late Aptian-Early Albian age, and the second of Middle Albian.

\section{GENESIS}

The rocks, sedimentary structures, fossils and palynomorphs found in the Itapecuru Formation support the interpretation of a fluvial depositional system, with predominantly fine deposits, with small lakes in floodplains, in an oxidizing environment and marked by seasonality. 


\section{CORRELATION}

According to the above biostratigraphic data, compared to other basins, the Itapecuru Formation is chronocorrelated with the Alter do Chão Formation of Solimões and Amazonas basins (Wanderley Filho et al. 2007, Cunha et al. 2007), and with the Araripina Formation of Araripe Basin (Assine 2007).

\section{DISCUSSION}

This new study of the Itapecuru Formation verified the predominance of very fine-grained lithofacies, and the studies of Ferreira et al. (1992), Carvalho (1994), Lovato et al. (1995), Gonçalves and Carvalho (1996) and F.J. Corrêa-Martins (unpublished data) support these results. Data from wells drilled in the north of the Parnaíba Basin near the city of Itapecuru-Mirim (Godoy and Rezende 1975, Soares Filho 1998), shows consistently that rocks found in the Itapecuru Formation, with thickness ranging up to $220 \mathrm{~m}$, are claystones and siltstones and, to a lesser extent, fine to very fine wackes. In wells drilled for Petrobras close to the same region, Mesner and Wooldridge (1962) and Lovato et al. (1995) also verified the predominance of mudrock in the Itapecuru Formation. In addition, it is emphasized that the water wells and the well PAF7-MA of Petrobras are located around $10 \mathrm{~km}$ from the proposed neostratotype (Figure $4 \mathrm{~b}$ ).

The fossiliferous content found in the Itapecuru Formation is compatible with the interpretation of a continental and freshwater paleoenvironment. In addition, the fossil of Candidodon itapecuruense (UFRJ-DG 113-R), a reptile with terrestrial life habit (Carvalho 1994, Nobre 2004), conserves part of the rock in which it was found in the destroyed type section, is correlated with the lithofacies Sil of the association of lithofacies CS described in this study.

Other studies have shown that the concentration of chemical element Boron is related to the salinity of water during sedimentation. In research conducted for CPRM in the rocks of Parnaíba Basin, Lins (1978) found that of 74 samples collected from the Itapecuru Formation, 34 samples contained Boron, but the quantities were considered uniformly low, characterizing a continental nonsaline depositional paleoenvironment. Besides the samples collected in the neostratotype, other 50 samples from the Itapecuru Formation were collected in the Itapecuru-Mirim, Santa Rita, Bacabeira and Rosário counties for geochemical analyses (F.J. Corrêa-Martins, unpublished data). The Boron mean values found in these samples varying between $<1$ and $2 \mathrm{ppm}$, corroborating the interpretation of Lins (1978).

The apparent contradiction between the results obtained and the previous studies is result of several questions.

Campbell (1949) defined the Itapecuru Formation with three members (Figure 3a), the lower Serra Negra, essentially consisting of sandstones, sometimes conglomeratic, while the other two, Undifferentiated and Boa Vista, constituted predominantly by claystone and siltstone, with the presence of clayey sandstones (Campbell 1949), i.e., wackes (Gilbert 1954, Dott 1964, Pettijohn et al. 1972, Boggs 2009).

The geological mapping carried out by Lima and Leite (1978) showed that the existing rocks in the type localities for the Serra Negra and Boa Vista members, located more than $200 \mathrm{~km}$ south of Itapecuru-Mirim city, belong to the oldest formations. As a result, the initial definition proposed by Campbell $(1949,1950)$, and simplified by Mesner and Woodridge $(1962,1964)$ was no longer valid.

The contact relationship between the Grajaú, Codó and Itapecuru formations is well known in outcrops, being characterized as predominantly gradational between the mentioned units, and the unconformities are of local character (CorrêaMartins et al. 2016). Therefore, the proposed 
discordances by Rossetti (2001) and Vaz et al. (2007) for the Grajaú, Codó and Itapecuru formations based on gamma-ray and seismic data, occur within the formations, and need to be reevaluated.

This research retrieves the original characterizations proposed by Campbell (1949). Together with the results of the field work, petrography and granulometry, the paleontological and geochemical data of the neostratotype and Rosário, Bacabeira, Santa Rita and ItapecuruMirim counties (F.J. Corrêa-Martins, unpublished data), shows that the Itapecuru Formation is mainly composed of silty claystones and clayey siltstones, while rocks such as fine wackes and others are subordinate. These very fine-grained rocks were deposited in a low energy subenvironment belonging to an anastomosed fluvial system, under paleo-oxidants conditions, as represented in the neostratotype presented here.

The advance of lithostratigraphy knowledge of the Parnaíba Basin (e.g. Aguiar 1969, 1971, Carneiro 1974, Lima and Leite 1978), allows to correlate the described lithologies of the former Serra Negra Member (Campbell 1949, 1950) with the rocks of Grajaú Formation (Figure 3a).

Thus, the medium to coarse sandstones, and sometimes conglomerates, which have been described as belonging to the Itapecuru Formation by many authors, are in fact lithofacies of the Grajaú Formation.

\section{CONCLUSIONS}

The formalization of neostratotype of the Itapecuru Formation on the right bank of the Itapecuru River, near the city of Itapecuru-Mirim, allowed the characterization of this lithostratigraphic unit as predominantly mudrock, resulting from low-energy river system in warm semi-arid paleoclimatic conditions and with marked seasonality. These results modify the lithological characterization of the unit, which was previously considered predominantly psammitic.

This study demonstrated that the medium to coarse sandstones, and conglomerates previously included in the Itapecuru Formation belong to the Grajaú Formation. Thus, it is suggested to carry out works aiming at a better characterization of this lithostratigraphic unit.

The changes proposed in this paper indicate the need to review the geological mapping of the Mesozoic section of the Parnaíba Basin.

\section{ACKNOWLEDGMENTS}

The author wishes to thank Petrobras for access to internal reports properly referred in this work. A debt of gratitude is likewise owed to Departamento Nacional de Infraestrutura de Transportes (DNIT), Ministry of Transport, for information about repairs carried out at Itapecuru River road bridge, and CPRM for access to reports of drilled water wells in the 1970s and 1990s. The author would like to thank Dr. Julio Cezar Mendes, Dr. Claudio Limeira Mello and Dr. Renata da Silva Schmitt (UFRJ), and Dr. Sérgio Brandolise Citroni (UFRRJ) for their evaluation and comments. In the same way, would like also to thank the two anonymous reviewers and associate editor for their helpful reviews and insightful comments. Through this research, the author would like to tribute the Museu Nacional do Rio de Janeiro/UFRJ, for its bicentennial, the Course of Geology of UFRJ, for its diamond jubilee, and the Course of Geology of UFRRJ, for its gold jubilee.

\section{REFERENCES}

AGUIAR GA. 1969. Bacia do Maranhão: Geologia e Possibilidade de Petróleo. [Belém]: Petrobras, DEPEX/ SEDOC, Relatório n ${ }^{\circ} 371$, p. 12, 15-46.

AGUIAR GA. 1971. Revisão Geológica da bacia Paleozóica do Maranhão. In: Congresso Brasileiro de Geologia, 25, 1971, São Paulo. Anais 3: 113-122.

ANAISSE JR J, TRUCKENBRODT W AND ROSSETTI DF. 2001. Fácies de um sistema estuarino-lagunar no Grupo 
Itapecuru, região de Açailândia/MA, Bacia do Grajaú. In: Rossetti DF, Góes AM and Truckenbrodt W (Eds), O Cretáceo na Bacia de São Luís-Grajaú. Belém, Museu Paraense Emílio Goeldi, p. 119-150.

ARANHA LGF, LIMA HP, SOUZA JMP AND MAKINO RK. 1990. Origem e evolução das bacias de Bragança-Viseu, São Luís e Ilha Nova. In: Raja Gabaglia GP and Milani EJ (Coord), Origem e evolução de bacias sedimentares, Rio de Janeiro: Petrobras, p. 221-233.

ARANHA LGF, LIMA HP, SOUZA JMP, MAKINO RK AND FIGUEIRAS AJM. 1988. Evolução Tectônica e Sedimentar das Bacias de Bragança-Viseu, São Luís e Ilha Nova. In: Congresso Brasileiro de Geologia, 35, 1988, Belém. Anais 6: 2487-2498.

ASSINE ML. 2007. Bacia do Araripe. B Geoci Petrobras 15: 371-389.

BAPTISTA MB, BRAUN OPG AND CAMPOS DA. 1984. Léxico Estratigráfico do Brasil, Brasília: DNPM/CPRM, $560 \mathrm{p}$.

BOGGS S. 1995. Principles of Sedimentology and Stratigraphy, $2^{\text {nd }}$ ed., Englewood Cliffs: Prentice Hall, 774 p.

BOGGS S. 2006. Principles of Sedimentology and Stratigraphy, $4^{\text {th }}$ ed., Upper Saddle River: Pearson Prentice Hall, 662 p.

BOGGS S. 2009. Petrology of Sedimentary Rocks, $2^{\text {nd }}$ ed., New York: Cambridge University Press, 600 p.

BRITO NEVES BB, FUCK RA, CORDANI UG AND THOMAS FILHO A. 1984. Influence of basement structures on the evolution of the major sedimentary basins of Brazil: A case of tectonic heritage. J Geodyn 1: 495-510.

BURNS CE, MOUNTNEY NP, HODGSON DM AND COLOMBERA L. 2017. Anatomy and dimensions of fluvial crevasse-splay deposits: Examples from the Cretaceous Castlegate Sandstone and Neslen Formation, Utah, U.S.A. Sediment Geol 351: 21-35.

CAMPBELL DF. 1949. Revised report of the Reconnaissance Geology of the Maranhão Basin, [São Luís, Rio de Janeiro:] CNP/DEPEX/SEDOC 103-00093, 117 p. + anexos.

CAMPBELL DF. 1950. Bacia do Maranhão (Geologia). In: Conselho Nacional Do Petróleo, Relatório de 1949. Rio de Janeiro, p. 81-85.

CAMPBELL DF, ALMEIDA LA AND SILVA SO. 1949. Relatório preliminar sobre a geologia da bacia do Maranhão. Rio de Janeiro: Conselho Nacional do Petróleo, Bol. 1, 160 p.

CAMPBELL DF, PLUMMER FB AND BRAZIL JJ. 1948. Estados do Maranhão e Piauí. In: Conselho Nacional Do Petróleo, Relatório de 1947. Rio de Janeiro: Conselho Nacional do Petróleo, p. 71-78.

CAMPOS CWM. 1964. Estratigrafia das bacias paleozoica e cretácea do Maranhão. Estudo especial preparado pelos geólogos J.C. Mesner e L.C. Wooldridge em 1962. B Téc Petrobras 7: 137-164.
CARNEIRO RG. 1974. Mapeamento estrutural da área Grajaú-Imperatriz, [Belém:] Petrobras, DIREX/RENOR, Relatório Técnico n ${ }^{\circ} 398,30$ p.

CARVALHO IS. 1994. Candidodon: um crocodilo com heterodontia (Notosuchia, cretáceo Inferior - Brasil). An Acad Bras Cienc 66: 331-346.

CARVALHO IS AND CAMPOS DA. 1988. Um mamífero triconodonte do Cretáceo Inferior do Maranhão, Brasil. An Acad Bras Cienc 60: 437-446.

CERQUEIRA JR AND MARQUES LFSP. 1985. Avaliação geoquímica da Bacia de São Luís. Rel Téc, [Rio de Janeiro] CENPES/Petrobras 351: 1-19.

CORRÊA-MARTINS FJ, ASSIS AP, MENDES JC AND SCHMITT RS. 2016. Considerações sobre o Mesozoico da Bacia do Parnaíba. In: Congresso Brasileiro de Geologia, 48, 2016, Porto Alegre: SBG, Anais ..., único, p. 9074.

CUNHA FMB. 1968. Fotointerpretação da bacia de São LuísMaranhão, Belém: PETROBRAS/RENOR. Relatório Técnico 318: 22.

CUNHA BCC AND DEL'ARCO JO. 1988. Variações faciológicas da Formação Itapecuru na região de Santa Inês - MA. In: Congresso Brasileiro de Geologia, 35, 1988, Belém. Anais 2: 765-777.

CUNHA PRC, MELO JHG AND SILVA OB. 2007. Bacia do Amazonas. B Geoci Petrobras 15: 227-251.

DALRYMPLE M. 2010. Interpreting sedimentary successions: facies, facies analysis and facies models. In: James NP and Dalrymple RW (Eds), Facies Models 4, Geological Association of Canada, St. John's, Newfoundland, GEO Text 6: 3-18.

DALY MC, ANDRADE V, BAROUSSE CA, COSTA R, MCDOWELL K, PIGGOTT N AND POOLE AJ. 2014. Brasiliano crustal structure and the tectonic setting of the Parnaíba basin of NE Brazil: Results of a deep seismic reflection profile. Tectonics 33: 2102-2120.

DOTT JR RH. 1964. Wacke, graywacke, and matrix - what approach to immature sandstone classification? J Sediment Petrol 34: 625-632.

EBERTH DA AND MIALL AD. 1991. Stratigraphy, sedimentology and evolution of a vertebrate-bearing, braided to anastomosed fluvial system, Cutler Formation (Permian-Pennsylvanian), north-central New Mexico. Sediment Geol 72: 225-252.

FERREIRA CS, AZEVEDO SAK, CARVALHO IS, GONÇALVES RA AND VICALVI MA. 1992. Os fósseis da Formação Itapecuru. In: Simpósio sobre as Bacias Cretácicas Brasileiras, 2, 1992, Rio Claro. Boletim de Resumos Expandidos, p. 107-110.

FERREIRA CS, CARVALHO IS, VICALVI MA, SANTOS MECM, CARVALHO MSS AND EUGENIO WS. 1991. Novas ocorrências de fósseis na Formação Itapecuru, Cretáceo do Maranhão. An Acad Bras Cienc 63: 98-99.

FERREIRA CS, VICALVI MA AND CARVALHO IS. 1995. A malacofauna dulcícola da Formação Itapecuru (Bacia do Parnaíba-Cretáceo Inferior). An Acad Bras Cienc 67: 381-382. 
FERREIRA NN, FERREIRA EP, RAMOS RC AND CARVALHO IS. 2016. Palynological and sedimentary analysis of the Igarapé Ipiranga and Querru 1 outcrops of the Itapecuru Formation (Lower Cretaceous, Parnaíba Basin), Brazil. J S Am Earth Sci 66: 15-31.

FORTES FP. 1978. Geologia Estrutural e Tectônica da Bacia Sedimentar do Meio-Norte do Brasil (Uma Síntese com Implicações Metalogenéticas). In: Congresso Brasileiro de Geologia, 30, 1978, Recife. Anais 1: 321-336.

GILBERT CM. 1954. Sedimentary rocks. In: Williams H et al., Petrography: An Introduction to the Study of Rocks in Thin Sections, [1st ed.,] San Francisco: W. H. Freeman, p. 249-384

GODOY LP AND REZENDE HP. 1975. Projeto CAEMA - Relatório Final do Poço 4MI-10-MA [Miranda do Norte, MA]. Recife: Companhia de Pesquisa de Recursos Minerais, n.p.

GÓES AM AND COIMBRA AM. 1996. Bacias sedimentares da província sedimentar do meio-norte do Brasil. In: Simpósio de Geologia da Amazônia, 5, Belém, 1996. Boletim, 1996, p. 186-187.

GÓES AM AND ROSSETTI DF. 2001. Gênese da Bacia de São Luís-Grajaú, Meio-Norte do Brasil. In: Rossetti DF et al. (Eds), O Cretáceo na Bacia de São Luís-Grajaú, Belém: Museu Paraense Emílio Goeldi, p. 15-29.

GÓES AM, ROSSETTI DF AND COIMBRA AM. 1999. A Bacia do Grajaú, estado do Maranhão, Brasil. In: Simpósio sobre o Cretáceo no Brasil, 5, Simpósio sobre el Cretácico de América del Sur, 1, Serra Negra, São Paulo, 1999. Boletim de Resumos Expandidos, 1999, p. 255-261.

GÓES AMO AND FEIJÓ FJ. 1994. Bacia do Parnaíba. B Geoci Petrobras, Rio de Janeiro, 8: 57-67.

GONÇALVES RA AND CARVALHO IS. 1996. Contribuição ao estudo da sedimentação da Formação Itapecuru - região de Itapecuru-Mirim, Bacia do Parnaíba (Cretáceo Inferior) - Maranhão - Brasil. Revista de Geologia 9: 75-81.

HEDBERG HD. 1976. International stratigraphic guide: a guide to stratigraphic classification, terminology, and procedure, New York: J Wiley \& Sons, 200 p.

KLEIN EL AND SOUSA CS. 2012. Geologia e Recursos Minerais do Estado do Maranhão: Sistema de Informações Geográficas - SIG: texto explicativo dos mapas Geológico e de Recursos Minerais do Estado do Maranhão, Escala 1:750.000, Belém: Serviço Geológico do Brasil - CPRM, $152 \mathrm{p}$.

LAZAR OR, BOHACS KM, MACQUAKER JHS, SCHIEBER J AND DEMKO TM. 2015. Capturing Key Attributes of Fine-Grained Sedimentary Rocks In Outcrops, Cores, and Thin Sections: Nomenclature and Description Guidelines. J Sediment Res 85: 230-246.

LIMA EA AND LEITE JF. 1978. Projeto estudo global de recursos minerais da Bacia do Parnaíba: integração geológica-metalogenética. Relatório Final da Etapa III, Recife, DNPM/CPRM, V 2, 3, 4 and 15.
LINOL B, DE WIT MJ, KASANZU CH, SCHMITT RS, CORREAA-MARTINS FJ AND ASSIS A. 2016. Correlation and Paleogeographic Reconstruction of the Cape-Karoo Basin Sequences and Their Equivalents Across Central West Gondwana. In: Linol B and De Wit MJ (Eds), Origin and Evolution of the Cape Mountains and Karoo Basin, Cham: Springer, p. 183-192.

LINS CAC. 1978. O Boro como elemento indicador de Paleosalinidade da Bacia do Parnaíba, Recife: SUREG/ CPRM, 21 p. Contribuição Técnica No 5350.004.

LISBOA MAR. 1914. The Permian Geology of Northern Brazil. Am J Sci 37: 425-443.

LOVATO OG, CAYE BR AND ARAUJO CC. 1995. Programa Levantamentos Geológicos Básicos do Brasil. Projeto especial mapas de recursos minerais de solos e de vegetação para a área do programa Grande Carajás. Subprojeto Recursos Minerais. Folha Itapecuru-Mirim. SA 23-Z-C, estado do Maranhão, escala 1:250.000, Brasília, CPRM, 93 p.

LUNDEGARD PD AND SAMUELS ND. 1980. Field classification of fine-grained sedimentary rocks. J Sediment Petrol 50: 781-786.

MENDES AC AND TRUCKENBRODT W. 2009. Proveniência de arenitos albianos (Grupo Itapecuru), borda leste da bacia de São Luís-Grajaú, Maranhão, usando análise de minerais pesados e química mineral. Bol Mus Para Emílio Goeldi, sér. Ciências Naturais 4: 57-74.

MENEZES TR AND CARVALHO IS. 1996. Análise dos argilominerais da seção-tipo da Formação Itapecuru (bacia do Parnaíba, estado do Maranhão). In: Congresso Brasileiro de Geologia, 39, 1996, Salvador. Anais 4: 314316.

MESNER JC AND WOOLDRIDGE LCP. 1962. The Maranhão Basin Study Revision, [Belém:] [Petrobras], DEPEX/SEDOC 103-00645, $2 \mathrm{v}$.

MESNER JC AND WOOLDRIDGE LCP. 1964. Maranhão Paleozoic basin and Cretaceous coastal basins, north Brazil. Bull Am Assoc Petrol Geol 48: 1475-1512.

MIALL AD. 1978. Lithofacies types and vertical profile models in braided river deposits: a summary. In: Miall AD (Ed), Fluvial sedimentology, Calgary: Can Soc Petrol Geol Mem 5: 597-604.

MIALL AD. 1996. The geology of fluvial deposits, Berlin: Springer, $582 \mathrm{p}$.

MIALL AD. 2016. Stratigraphy: A Modern Synthesis, Heildelberg: Springer, $454 \mathrm{p}$.

MIRANDA MCC AND ROSSETTI DF. 2006. Reconstituição paleoambiental de depósitos albianos na borda leste da bacia de Grajaú, MA. Rev Bras Geocienc 36: 623-635.

MUNSELL. 2009. Geological Rock-Color Chart, Grand Rapids: Munsell Color.

MURPHY MA AND SALVADOR A. 1999. International Stratigraphic Guide - An Abridged Version. International subcommission on stratigraphic classification of IUGS International Commission on Stratigraphy. Episodes 22: 255-272. 
NANSON GC AND CROOKE JC. 1992. A genetic classification of floodplains. Geomorphology 4: 459-486.

NASCIMENTO MS AND GÓES AM. 2007. Petrografia de arenitos e minerais pesados de depósitos cretáceos (Grupo Itapecuru), Bacia de São Luís-Grajaú, norte do Brasil. Rev Bras Geocienc 37: 50-63.

NASCIMENTO MS, GÓES AM, MACAMBIRA MJB AND BROD JA. 2007. Provenance of Albian sandstones in the São Luís-Grajaú Basin (northern Brazil) from evidence of $\mathrm{Pb}-\mathrm{Pb}$ zircon ages, mineral chemistry of tourmaline and palaeocurrent data. Sediment Geol 201: 21-42.

NOBRE PH. 2004. Morfologia pós-craniana de Candidododon itapecuruense (Crocodylomorpha, Mesoeucrocodylia), do Cretáceo do Brasil. Rev Bras Paleontolog 7: 87-92.

PEDRÃO E. 1995. Palinoestratigrafia e evolução paleoambiental de rochas sedimentares aptianascenomanianas das bacias de Bragança-Viseu e São Luís, 215 p. Dissertação de Mestrado, Universidade Federal do Rio de Janeiro, Rio de Janeiro. (Unpublished).

PEDRÃO E, ARAI M, BARRILARI IMR AND CARVALHO IS. 1993. Análise palinológica de uma amostra de superfície de Querru (Formação Itapecuru), município de ItapecuruMirim (MA). In: Congresso Brasileiro de Paleontologia, 13, e Simpósio Paleontológico do Cone Sul, 1, 1993, São Leopoldo. Boletim de Resumos, p. 175-175.

PEDRÃO E AND CORREAA-MARTINS FJ. 1999. Palinoestratigrafia de um afloramento da Formação Itapecuru (Bacia do Parnaíba) em Rosário, Estado do Maranhão: Correlações Cronoestratigráficas. An Acad Bras Cienc 71: 767-776.

PETRI S, COIMBRA AM, AMARAL G, OJEDA Y, OJEDA HA, FÚLFARO VJ AND PONÇANO WL. 1986. Código Brasileiro de Nomenclatura Estratigráfica/Guia de Nomenclatura Estratigráfica. Rev Bras Geocienc 16: 372376.

PETTIJOHN FJ, POTTER PE AND SIEVER R. 1972. Sand and Sandstone, $1^{\text {st }}$ ed., Berlin: Springer-Verlag, 618 p.

PICARD DM. 1971. Classification of fine-grained sedimentary rocks. J Sediment Petrol 41: 179-195.

POTTER PE, MAYNARD JB AND DEPETRIS PJ. 2005. Mud and Mudstones: Introduction and Overview, Berlin: Springer, $297 \mathrm{p}$.

PRICE LI. 1947. Sedimentos mesozóicos na Baía de São Marcos, Estado do Maranhão. Notas Preliminares e Estudos da Divisão de Geologia e Mineralogia, Rio de Janeiro 40: 8 .

RETALLACK GJ. 1988. Field recognition of paleosols. In: Reinhardt J and Sigleo WR (Eds), Paleosols and weathering through geologic time: Principles and applications. Geol Soc Am Spec Paper, Boulder 216: 1-20.

ROSSETTI DF. 2001. Arquitetura deposicional da Bacia de São Luís-Grajaú, Meio-Norte do Brasil. In: Rossetti DF et al. (Eds), O Cretáceo na Bacia de São Luís-Grajaú. Belém: Museu Paraense Emílio Goeldi, p. 31-46.

ROSSETTI DF AND GÓES AM. 2003. Caracterização Paleoambiental de Depósitos Albianos da borda sul da Bacia de São Luís-Grajaú: Modelo de delta fluvial influenciado por tempestade. Rev Bras Geocienc 33: 299312.

ROSSETTI DF, GÓES AM AND ARAI M. 2001. A passagem Aptiano-Albiano na Bacia de São Luís-Grajaú, MA. In: Rossetti DF et al. (Eds), O Cretáceo na Bacia de São LuísGrajaú. Belém: Museu Paraense Emílio Goeldi, p. 101117.

ROSSETTI DF, GÓES AM, TRUKENBRODT W AND ANAISSE JR J. 2000. Tsunami induced large-scale scourand-fill structures in Albian to Cenomanian deposits of Grajaú Basin, Northern Brazil. Sedimentology 47: 309323.

ROSSETTI DF AND TRUKENBRODT W. 1997. Revisão estratigráfica para os depósitos do Albiano-Terciário Inferior (?) na Bacia de São Luís, Maranhão. Bol Mus Para Emílio Goeldi, sér. Ciências Naturais 9: 31-43.

SACHS LLB, ALCANTARA KC AND MENDES VA. 2017. Projeto materiais de construção da região metropolitana de São Luís e entorno. Estado do Maranhão, Teresina: CPRM, $341 \mathrm{p}$.

SANTOS JQ AND MAMEDE VM. 1990. Litofácies e Sistemas Deposicionais da Formação Itapecuru na Porção Centro-Oeste do Estado do Maranhão. In: Congresso Brasileiro de Geologia, 36, 1990, Natal. Anais 1: 150-156.

SANTOS MECM AND CARVALHO MSS. 2009. Paleontologia das bacias do Parnaíba, Grajaú e São Luís. Reconstituições Paleobiológicas, Rio de Janeiro: CPRM Serviço Geológico do Brasil-DGM/DIPALE, 215 p.

SCHERER CMS, GOLDBERG K AND BARDOLA T. 2015. Facies architecture and sequence stratigraphy of an early post-rift fluvial succession, Aptian Barbalha Formation, Araripe Basin, northeastern Brazil. Sediment Geol 322: 43-62.

SIMON SST AND GIBLING MR. 2017. Fine-grained meandering systems of the Lower Permian Clear Fork Formation of north-central Texas, USA: Lateral and oblique accretion on an arid plain. Sedimentology 64: 714746.

SMITH ND, CROSS TA, DUFFICY JP AND CLOUGH SR. 1989. Anatomy of an avulsion. Sedimentology 36: 1-23.

SOARES FILHO AR. 1998. Programa Recursos Hídricos. Subprograma Água Subterrânea para a Região Nordeste: relatório final [do] Poço 4ITM-01-MA, Povoado Entroncamento, Município de Itapecuru Mirim, Estado do Maranhão, Teresina: CPRM.

STUART JY, MOUNTNEY NP, MCCAFFREY WD, LANG SC AND COLLINSON JD. 2014. Prediction of channel connectivity and fluvial style in the flood-basin successions of the Upper Permian Rangal coal measures (Queensland). AAPG Bulletin 98: 191-212.

VAZ PT, REZENDE NGAM, WANDERLEY FILHO JR AND TRAVASSOS WAS. 2007. Bacia do Parnaíba. B Geoci Petrobras 15: 253-263.

WANDERLEY FILHO JR, EIRAS JF AND VAZ PT. 2007. Bacia do Solimões. B Geoci Petrobras 15: 217-225. 